\title{
ENTRY DENIED: JAPAN'S BORDER RESTRICTIONS IN THE TIME OF THE COVID-19 EMERGENCY
}

\author{
Nicola COSTALUNGA
}

COBISS 1.01

\begin{abstract}
Entry Denied: Japan's Border Restrictions in the Time of the COVID-19 Emergency With the outbreak of SARS-CoV-2 and the resulting COVID-19 pandemic, Japan adopted controversial policies to contain the virus. Unlike many highly developed countries, it enacted strict policies banning entry through its borders to all nonJapanese citizens regardless of their residency status. The further peculiarity is that these measures equalized low-skill and high-skill foreign workers, affecting them identically. Along with describing how the emergency has been handled in relation to foreign nationals, this article highlights how pre-existing socio-cultural dynamics of differentiation between "insiders" and "outsiders" have evolved in response to the pandemic.
\end{abstract}

KEYWORDS: Japan, borders, migration policies, COVID-19, denial of entry

\section{IZVLEČEK}

Vstop zavrnjen: Japonske mejne omejitve v času izrednih razmer med pandemijo Covida-19

Z izbruhom virusa SARS-CoV-2 in posledično pandemije Covida-19 je Japonska za zajezitev virusa sprejela sporne ukrepe. V nasprotju s številnimi visoko razvitimi državami je vsem nejaponskim državljanom, ne glede na njihov bivalni status, strogo prepovedala prehajanje meja. Ti ukrepi so enako prizadeli tako visoko- kot nizkokvalificirane tuje delavce. Članek obravnava izvajanje izrednih ukrepov v povezavi s tujci, hkrati pa pojasnjuje razvoj že obstoječe sociokulturne dinamike razlikovanja med »našimi« in „vašimi« ob soočenju s pandemijo.

KLJUČNE BESEDE: Japonska, meje, migracijske politike, Covid-19, zavrnitev vstopa

$\mathrm{PhD}$ student in global studies, justice, rights, politics, University of Macerata; Piazza Strambi 1, 62100 Macerata (MC), 36030, Italy; n.costalunga@unimc.it; https://orcid.org/0000-0001-82548405. 


\section{INTRODUCTION}

The crisis caused by the virus responsible for COVID-19 is not over yet, and the battle to return to a pre-crisis state is likely to be a long one. The virus SARS-CoV-2 has changed the social dynamics that we have all taken for granted. Our current situation seems to be an all-encompassing "revolution" in social, economic, political, and cultural life.

Japan is a prominent case regarding the paradoxes that have emerged from the pandemic: on the one hand, it has always been reluctant to accept non-skilled foreign workers to overcome its structural and labor shortage problems, while on the other, for the first time in its history, it opened up (albeit in a limited way) to low and semi-skilled immigration in 2018 (Hamaguchi 2019: 2-5). However, shortly after this opening, Japan faced the unforeseen consequences that the novel coronavirus brought to its migration policies.' The paradox is that, at this historical moment of Japan's opening to a type of immigration that had hitherto been rejected, COVID-19 revived, broadened, and strengthened closure policies, also affecting those who have lived and worked in Japan for years, i.e., permanent and long-term foreign nationals (Arudou 2020c; 2020d).

This article describes how the pandemic emergency has been handled in Japan in relation to foreign nationals living in the archipelago and how Japan's response to security and health concerns in this respect has exacerbated pre-existing problematic dynamics and racial issues in its society. My argumentation is based on the results of research conducted on secondary sources varying in length and argumentative depth. As the situation is constantly evolving and because of the shortage of academic material due to the recentness of the topic, online articles, blog posts, and online interviews made up the majority of the consulted literature. First, I sum up the theory of the dynamics related to migration and control policies in general, focusing on differentiated treatment, border control issues, and cultural peculiarities. On these grounds, the second part introduces the events related to the re-entry ban for foreigners into Japan in 2020 and discusses the differentiation tendencies present in today's Japanese society. The conclusion provides speculations and forecasts about the present and future of the problem of social "othering" in Japan.

This article's key findings highlight how the dynamics of differentiation already embedded in the Japanese society between those who are part of it ("insiders"/Japanese) and those who are excluded ("outsiders"/foreigners) (Reischauer 1995: 396; Brody 2002: 1-7), have changed and evolved in response to the peculiarity of the COVID-19 emergency. The almost unique feature of this situation is that, although usually high-

1 Japan has been criticized for having one of the most restrictive migration policies among advanced industrial countries (Tsuda, Cornelius 2004: 449), based on control and lacking in policies of social incorporation or active socio-political participation (Shipper 2008: 25). For further discussion, see Tsuda and Cornelius (2004) and Shipper (2008). On issues concerning public policy and racial discrimination, see Arudou (2015). 
skilled migrant workers are in a privileged position compared to low-skilled migrant workers in the receiving societies, this binary division between insiders and outsiders has exceptionally equalized, balanced, and almost flattened the difference in Japan between foreign blue-collars and foreign managers (and also foreign investors), bringing them together in the social differentiation and exclusionary process within the archipelago.

\section{BORDERS, MIGRATION, MULTICULTURALISM, AND CONTROL}

Borders traditionally create a geographical separation of different political entities and legal jurisdictions. Through them, the state controls its territory, the mobility of people, and security. Moreover, they have the function of dividing not only physical territories but people, too (Loftus 2015: 115). Borders act as a separating element between different categories of people, filtering out those who can be admitted and be a part (to varying degrees) of the country and those who must be excluded. Border regimes can act as a dividing element of gender (Gerard, Pickering 2012: 514-533), race, and ethnicity (Weber, Bowling 2008: 355-375), but also of other social categories. How national policies and laws control and exclude specific categories of people are part of border enforcement policies (Bosworth 2008: 199-215). The ability to move across international borders depends on national migration policies, which in turn depend on a specific national policy regime. Migration policy regimes have not been immutable, and their present-day "cumbersomeness" is a very recent construct. Indeed, the transformation from a "free-entry" regime to one of control and regulation was triggered by the development of the concept of "citizenship" and its legal recognition, ${ }^{2}$ which has triggered an increasingly complex and heterogeneous regulatory and normative evolution of national migration policies (Klugman, Pereira 2009).

In this analysis, the context of border policies is the COVID-19 pandemic, which overlaps with the rules and laws of the pre-existing national migration structures. The application of strict directives on entry into and exit from a country at a time of a pandemic crisis, even to the point of total closure of the nation, is undoubtedly driven by social and health security logics. What is surprising about Japan's border restrictions is the process of differentiation between insiders and outsiders, which is not new at all in Japanese society (Arudou 2015).

2 The time of introducing the concept of citizenship varies by country. For example, such historical countries as France and Australia introduced the concept of citizenship in the nineteenth century and the mid-twentieth century, respectively (Klugman, Pereira 2009). 
Furthermore, Japan is in the so-called age of tabunka kyōsei (multicultural coliving), ${ }^{3}$ a concept prevailing since the $1990 \mathrm{~s}^{4}$ in the integration practices of migrants in Japanese society (Kashiwazaki 2013: 31-47). Broadly speaking, tabunka kyōsei is a concept of coexistence between Japanese citizens and foreign nationals, in a mutual effort to create a society in which people live and work together, with the respect attributed to living within the same community, regardless of nationality or ethnic background. In this idea also lie concepts of cultural diversity and the general fight against forms of racism (Kashiwazaki 2013: 39-42). However, tabunka kyōsei practices have failed to eliminate the fundamental dichotomy in Japanese society between Japanese and foreigners, ${ }^{5}$ maintaining this implicit institutionalized polarization, not least because the Japanese government has refused to make the multicultural question a matter of national debate (Kashiwazaki 2009: 121-146). This apparent paradox and persistent division within a broader policy of "multiculturalism" can also be glimpsed in the adaptive differentiation between insiders and outsiders that re-emerged in response to COVID-19 and related border policies.

\section{NEW IMMIGRATION LAW, OLD PARADOXES}

On December 8, 2018, Japan's Diet passed a historic amendment to the Immigration Control and Refugee Recognition Act (ICRRA), establishing for the first time the possibility for low and semi-skilled foreign workers to enter and work in the country (Hamaguchi 2019: 2-5). ${ }^{6}$ Although the amendment is not utterly revolutionary as it allows the entry of foreign workers with strict limits, for the first time, there has been a step back from the constant official Japanese policy rhetoric of "closing" to any form of non-skilled immigration. In fact, the law enabled in April 2019 two new residency statuses, the tokutei ginō ichi gō (specified skilled type 1) and the tokutei ginō ni gō

3 Literally, "multi-cultural-together-living", translatable as "multicultural coexistence," too. It can be considered as the Japanese version of multiculturalism. However, it is quite distinct from tabunka shugi, a term associated with multiculturalism in classic immigration countries (e.g., the USA, Canada, and Australia), as they are considered extremely different from the Japanese society (Kashiwazaki 2013: 31-32; 2016: 4-5). For more on tabunka kyōsei and its origins, see Kashiwazaki $(2013,2016)$.

4 The notion has only entered the vocabulary of local and national policy-making institutions since the 2000s (Kashiwazaki 2013: 41).

5 Morris-Suzuki criticized tabunka kyōsei describing it as "cosmetic multiculturalism" since it is based on the binary opposition between Japanese and foreigners (Morris-Suzuki 2002).

6 Since the 1980s, the government has introduced several amendments to ICRRA, each time proposing amendments for opening the country to some forms of unskilled labor. The most important ones were the 1989 amendment that resulted in the creation of the "side door" for South American nikkeijin, Japanese emigrants and their descendants, especially from Brazil and other South American countries (Brody 2002: 2-4, 53-86; Shipper 2008: 25-26, 37-41), the creation of the Technical Intern Training Program in 1993 that introduced foreign "trainees" and "technical interns," and the Technical Internship Act of 2016 that changed the overall length of the technical intern program (Hamaguchi 2019: 2-5). 
(specified skilled type 2), the former of which allows low and semi-skilled laborers to enter and work in the country.

The significance of this amendment was far-reaching since, until the end of 2018, Japan had always been a country that refused to rely on immigration ${ }^{7}$ despite its structural problems of low birth rate, rapidly aging population, and shrinking working-age population. ${ }^{8}$ Its position was almost unique among OECD countries, at least for the constancy with which it "imposed" itself on this line of thought.

However, COVID-19 has created an unexpected situation wherein not only did Japan's labor market suffer a severe setback (as did all global production systems), but it also caused policy choices pointing against the process of "opening up" to immigration; a process that had only started in late 2018.

At the beginning of the health crisis, the Japanese government closed the archipelago to the entry of any foreigners, even those with permanent resident status, with lives and families in the archipelago. ${ }^{9}$ The re-entry restrictions placed all non-Japanese citizens ineligible for re-entry, making their statuses the same as those of tourists, metaphorically, "guests."10

Since April 3, 2020, when a general closure of the country's borders against any form of inbound travel was declared," Japan has had a unique policy toward foreigners. All foreign residents who were abroad at the time have generally been banned from re-entering in Japan (even permanent and long-term residents), ${ }_{1}^{12}$ except for a limited set of extraordinary humanitarian cases (Dooley 2020). Japanese nationals could freely leave and re-enter the archipelago after being subjected to testing and subsequent quarantine (Arudou 2020d). This measure had the further effect of locking foreign nationals inside the country for fear of not being able to return, thus precluding them from going back to their country of origin. The method for determining the limited cases of "humanitarian" nature even remained unclear, relegating the discretion of choice to the immigration officials assigned to each case (Kopp 2020a).

7 There is a discrepancy between the official stance of the Japanese government and the de facto immigration situation in the archipelago. Although there is a de facto immigration regime for semi-skilled and unskilled foreign workers through the various ICRRA amendments that have created different channels of entry to the country for categories such as South American nikkeijin and trainees, as well as marriage migration, officially Japan has not been open to any form of unskilled foreign labor. However, these specific forms of entry have de facto allowed creating so-called "side doors" as a legal solution to its endemic labor shortage problems (Brody 2002: 2-4, 40-43, 59).

8 For more information about Japan's structural problems, see Coulmas (2007), Suzuki (2013), and Dallin (2016).

9 Permanent residence in Japan is called eijū-ken.

10 Indeed, Arudou described this as "guestism" (2020c; 2020b).

11 As "a temporary measure aimed at curtailing the spread of viral transmissions in Japan" (Ōsumi 2020).

12 Long-term residence in Japan is called teijū-sha. 
This process of differentiation has deeper implications. Allowing only indigenous citizens to re-enter Japan unwittingly creates an ethnic association with being immune to the virus "by dint of a passport" (Arudou 2021). Vice versa, by reconstructing the origins of COVID-19 as something "foreign" (Arudou 2020a; Takahashi 2020; Su et al. 2020), non-Japanese citizens are categorized as more contagious than Japanese. Historically, it has already happened that during other epidemics, ${ }^{13}$ foreigners were considered more contagious or dangerous than Japanese, and even that Japanese were considered somehow immune to the virus (Arudou 2020a)..$^{14}$ Far from being the only country to have imposed travel limitations and border closure, Japan was the only member of the Group of Advanced Countries (G-7) to enforce such strict restrictions (Dooley 2020; Ōsumi 2020), thus becoming an outlier in respect to the other developed countries (Arudou 2020c).

Compared to a general history of the international community's indifference on matters related to foreigners' discrimination in Japan, this time, there was an unexpectedly high number of criticisms coming from various nationa ${ }^{15}$ and international authorities. For instance, president of the European Business Council in Japan (EBC) Michael Mroczek strongly criticized the travel restrictions imposed by the Japanese government during the pandemic, pointing out that there was a clear dissonance between the rigidity imposed on foreign nationals and Japanese citizens. This differential treatment could lead to heavy criticism from businesses dealing with transborder trades of goods and services, to the point of risking that they might decide to move their Asian headquarters to countries other than Japan (Mrozczek 2020; Penn 2020).

After an initial joint statement on "Re-Entry of Foreign Residents to Japan" on behalf of the international business community (ACCJ 2020a), on July 7, 2020, the American Chamber of Commerce in Japan (ACCJ) issued a second letter of protest to the Japanese immigration authorities (Penn 2020), calling on the Japanese government to provide equal treatment for all citizens, regardless of nationality. Requests included a clear timetable for the reopening of travel and clearer and streamlined policies for re-entry admissions, noting that foreign nationals have contributed to the Japanese economy and society and pose no greater risk than Japanese citizens. Christopher J. LaFleur, Chairman of the American Chamber of Commerce in Japan,

13 For example, during other epidemics (SARS outbreak in 2002-2003 and H1N1 swine flu in 2009), hotels and other facilities refused to provide their services to foreigners, above all Chinese nationals, implying that the virus and contagiousness came from "outside" (Arudou 2020a).

14 Politicians and the media in turn instrumentalized COVID-19 by portraying it as a "foreign virus" and labeling it as "Wuhan virus" or "Chinese virus," thus hindering an accurate perception of the virus's origins and creating potential biases (Takahashi 2020; Su et al. 2020).

15 Noteworthy are an editorial published in the Asahi Shimbun of June 8, 2020, which called the re-entry ban policies "discriminatory" and "unreasonable," and the petition made by the Japan Association of National Universities requesting Japan's Ministry of Education to have their researchers and university students readmitted (Arudou 2020c). 
stated that "foreign residents of Japan who have made a decision to build a life here and contribute to the Japanese economy should not be subject to a double standard restricting their travel, economic, and familial opportunities based on nationality," and that "while we applaud and support the Japanese government's efforts to manage the COVID-19 crisis, a resident's nationality provides no basis on which to assess risk or assign travel privilege in relation to COVID-19" (ACCJ 2020b; 2020c). On July 22, 2020, during a conference of the Foreign Correspondents' Club of Japan, Mrozcezk and LaFleur reiterated the need for the Japanese government to end the travel ban on non-residents (Mrozcezk, LaFleur 2020). On August 19, 2020, the American Chamber of Commerce in Japan, the Australian and New Zealand Chamber of Commerce in Japan, the British Chamber of Commerce in Japan, and the European Business Council issued a new joint statement on Japan blocking the return of foreign residents (Penn 2020). According to them, these bans "can only discourage foreign nationals, and the companies they work for, from investing in Japan" (Okutsu, Regalado 2020; Ōsumi 2020).

Despite the easing of restrictions in August, September, ${ }^{16}$ and particularly in October, ${ }_{17}^{17}$ the biggest challenges for foreign residents were the necessity to deal with a lot of complicated paperwork, as well as to acquire a negative COVID-19 test within seventy-two hours of the departure time (Kopp 2020b). As of November 1, 2020, foreign national residents with a valid re-entry permit no longer needed to provide the "Letter of Confirmation of Submitting Required Documentation for Re-entry into Japan" or the "Receipt for request of re-entry," but they still needed to provide a test certificate to prove negativity to COVID-19 within seventy-two hours of departure for Japan (Immigration Services Agency of Japan 2020).

Such requests were addressed only to foreign citizens and not to Japanese citizens, preserving the process of binary differentiation between those who are part of the "inside" (uchi, the natives) and those who are part of the "outside" (soto, the foreigners). ${ }^{18} \mathrm{~A}$ paradox is evident, especially for permanent foreign nationals, who,

16 On September 25, 2020, the government announced that from October 1, 2020, it would have opened its borders to all foreign visitors who had permits to enter and stay in the country, including businesspeople and students, but not tourists (Penn 2020).

17 On October 7, 2020, Japan and South Korea resumed bilateral business travel, with shortterm business travelers not required to observe fourteen-day isolation periods if they were tested negative for COVID-19 and submitted their travel itineraries in advance (Penn 2020). However, several steps needed to be taken in all cases, such as obtaining a "Letter of Confirmation of Submitting Necessary Documentation for Re-Entry into Japan" from the embassy and a test certificate proving negativity to COVID-19 within 72 hours of departure for Japan (Arudou 2020d).

18 For further information about the concepts of uchi and soto, see Doi (1986). 
by definition, should have the right to stay permanently in Japan..$^{19}$ Through this devaluation of the intrinsic value of their residency status when crossing the country's borders, permanent foreign nationals were obliquely compared to mere tourists (Arudou 2020d). The uchi-soto dynamic can also be found in the assessment of the virus's discretionary infectiousness, as outlined above as regards to Japanese's immunity/foreigners' contagiousness.

\section{CONCLUSION}

What has been described so far is only part of an evolving story. At the time of writing this article (December 2020), Japan imposed a new ban on the entry of foreign nationals because of a new variant of COVID-19 detected in the country. The intervention of one part of the international (business) community, the protests of international entrepreneurs and foreign residents, have laid the foundations for a new approach to old problems within Japanese society. What does not seem to change, however, are the processes of othering in the treatment of uchi and soto that have long characterized Japan. This treatment is what Arudou refers to as embedded racism of Japanese society toward the foreigner/diverse/outsider (2015). In this particular time, the difference is that, in response to criticism from the international community, "regular Japanese racism has been replaced by a new, improved racism," where borders can become more elaborated racist barriers (2020d).

These dynamics of adaptation to the peculiarities of the emergency turn out to be just a new form of division, a new perspective on Reischauer's line of differentiation between the dichotomy uchi and soto, between Japanese and foreigners, whatever legal status they hold. ${ }^{20}$ From a broader perspective, these issues conflict with the extent to which Japanese reality is trying to emancipate itself from the stereotype of insular exclusivity, its own isolationist historicity, and the concepts of cultural homogeneity and uniqueness (Brody 2002: 1-2). The fragility of tabunka kyōsei, albeit indirectly, is further reflected in the exceptional nature of border policies

19 The measures described so far concerned all foreign nationals, with the exception of special permanent residents (tokubetsu-eijüsha) and, as described above, those who have special exceptional circumstances (OECD 2020). Special permanent residents are generally Korean and Chinese zainichi. The term zainichi refers to the group of Japan-born foreigners who have lived in Japan for several generations and have decided not to become naturalized. Specifically, their origins are rooted in those who migrated from colonial territories during the period of Japanese domination of Korea, Taiwan, and part of China (Japanese colonial empire, 1895-1945) and continue to their descendants (Lie 2008: ix-xiv; Shipper 2008: 27).

20 In a recent interview on the topic of migrant workers in the Japanese labor market with the Tōzen Union, its executive chairman, Okunuki Hifumi, and its Chief Financial Officer and founder, Louis Carlet confirmed that in Japanese society a basic assumption is present about the division between what is "inside" (Japanese) and what is "outside" (foreigner). According to them, this clear-cut demarcation is somehow immutable (interview with Tōzen Union, 10 Feb. 2021). 
under the stress of the pandemic. The same can be said for foreign workers living in Japan, as well as those who planned to migrate to or to invest economically within the archipelago.

\section{REFERENCES}

Arudou, Debito (2015). Embedded Racism. Japan's Visible Minorities and Racial Discrimination. London: Lexington Books.

Arudou, Debito (2020a). Visible Minorities: Japan's Botched Response to the Coronavirus, http://shingetsunewsagency.com/2020/02/17/visible-minorities-japans-botchedresponse-to-the-coronavirus/ (9 Jan. 2021).

Arudou, Debito (2020b). Visible Minorities: The Guestists and the Collaborators, http://shingetsunewsagency.com/2020/05/18/visible-minorities-the-guestistsand-the-collaborators/ (9 Jan. 2021).

Arudou, Debito (2020c). Visible Minorities: A Despotic Bridge Too Far, http://shingetsunewsagency.com/2020/07/20/visible-minorities-a-despotic-bridge-too-far/ (9 Jan. 2021).

Arudou, Debito (2020d). Visible Minorities: New Covid Foreign Resident Re-Entry Rules Still Racist, http://shingetsunewsagency.com/2020/10/19/visible-minorities-newcovid-foreign-resident-re-entry-rules-still-racist/ (9 Jan. 2021).

Arudou, Debito (2021). Visible Minorities: Latest Visa Rules Could Purge Any Foreigner, http://shingetsunewsagency.com/2021/01/18/visible-minorities-latest-visarules-could-purge-any-foreigner/ (20 Jan. 2021).

Bosworth, Mary (2008). Border Control and the Limits of the Sovereign State. Social and Legal Studies 17/2, 199-215, https://doi.org/10.1177/0964663908089611.

Brody, Betsy Teresa (2002). Opening the Doors: Immigration, Ethnicity, and Globalization in Japan. New York: Routledge.

Coulmas, Florian (2007). Population Decline and Ageing in Japan - The Social Consequences. New York: Routledge.

Dallin, Jack (2016). The Issue of Japan's Aging Population. Law School International Immersion Program Papers 8.

Doi, Takeo (1986). The Anatomy of Self: The Individual Versus Society. Tokyo: Kodansha International.

Dooley, Ben (2020). Japan's Locked Borders Shake the Trust of Its Foreign Workers, https://www.nytimes.com/2020/08/05/business/japan-entry-ban-coronavirus. html (20 Jan. 2021).

Gerard, Alison, Pickering, Sharon (2012). The Crime and Punishment of Somali Women's Extra-Legal Arrival in Malta. British Journal of Criminology 52/3, 514-533, https://doi.org/10.1093/bjc/azr094.

Hamaguchi, Keiichiro (2019). How Have Japanese Policies Changed in Accepting Foreign Workers?, Japan Labor Issues 3/14, 2-5. 
Kashiwazaki, Chikako (2009). The Foreigner Category for Koreans in Japan: Opportunities and Constraints. Diaspora without Homeland: Being Korean in Japan (eds. Sonia Ryang, John Lie). Oakland, CA: University of California Press, 121-146, https:// doi.org/10.1525/california/9780520098633.003.0007.

Kashiwazaki, Chikako (2013). Incorporating Immigrants as Foreigners: Multicultural Politics in Japan. Citizenship Studies 17/1, 31-47, https://doi.org/10.1080/1362102 5.2013.764216.

Kashiwazaki, Chikako (2016). Multicultural Discourse and Policies in Japan: An Assessment of Tabunka Kyōsei. The Gakushuin Journal of International Studies 3, 1-15.

Klugman, Jeni, Pereira, Isabel Medalho (2009). Assessment of National Migration Policies: An Emerging Picture on Admissions, Treatment and Enforcement in Developing and Developed Countries. Human Development Research Paper 2009/48.

Kopp, Rochelle (2020a). Re-entry Ban Causes Foreign firms and Talent to Question Longterm Plans in Japan, https://www.japantimes.co.jp/?post_type=community\& $\mathrm{p}=2686710$ (9 Jan. 2021).

Kopp, Rochelle (2020b). The Pandemic Border Policy that will Leave a Scar on Japan's Foreign Community, https://www.japantimes.co.jp/community/2020/12/07/issues/ pandemic-border-policy-foreign-community/ (9 Jan. 2021).

Immigration Services Agency of Japan, Ministry of Justice of Japan (2020). https:// www.isa.go.jp/en/index.html (15 Jan. 2021).

Lie, John (2008). Zainichi (Koreans in Japan): Diasporic Nationalism and Postcolonial Identity. Berkeley: University of California Press.

Loftus, Bethan (2015). Border Regimes and the Sociology of Policing. Policing and Society 25/1, 115-125, https://doi.org/10.1080/10439463.2013.802788.

Morris-Suzuki, Tessa (2002). Hihanteki sōzōryoku no tameni: Gurōbaruka jidai no Nihon. Tokyo: Heibonsha.

Mroczek, Michael (2020). Relaxing Travel and Entry Bans in Japan and Europe, https:// www.youtube.com/watch?v=PBjiA8-0dRs (5 Jan. 2021).

Mrozcezk, Michael, LaFleur, Christopher J. (2020). End Japan's Travel Ban on Non-Residents, https://www.youtube.com/watch?v=BjoUvNxn6tY (5 Jan. 2021)

OECD (2020). International Migration Outlook 2020. Paris: OECD Publishing, https:// doi.org/10.1787/ec98f531-en.

Okutsu, Akane, Regalado, Francesca (2020). Japan Finally Lifts COVID-based Re-entry Ban for Foreign Residents, https://asia.nikkei.com/Spotlight/Japan-immigration/ Japan-finally-lifts-COVID-based-reentry-ban-for-foreign-residents (9 Jan. 2021).

Ōsumi, Magdalena (2020).Japan's Entry Policies Increase Alienation and Deepen Division, https://www.japantimes.co.jp/news/2020/08/27/national/social-issues/japanentry-policies-coronavirus/ (19 Jan. 2021).

Penn, Michael (2020). Working Timeline of Covid-19 in Japan, http://shingetsunewsagency.com/2020/10/25/working-timeline-of-covid-19-in-japan/ (5 Jan. 2021).

Reischauer, Edwin O., Marius, Jansen B. (1995). The Japanese Today: Change and Continuity. Cambridge, MA: Belknap Press. 
Shipper, Apichai Wongsod (2008). Fighting for Foreigners: Immigration and Its Impact on Japanese Democracy. Ithaca, NY: Cornell University Press.

Su, Zhaohui, McDonnell, Dean, Ahmad, Junaid, Cheshmehzangi, Ali, Li, Xiaoshan, Meyer, Kylie, Cai, Yuyang, Yang, Ling, Xiang, Yu-Tao (2020). Time to Stop the Use of 'Wuhan Virus', 'China Virus' or 'Chinese Virus' across the Scientific Community. BMJ Global Health, https://doi.org/10.1136/bmjgh-2020-003746.

Suzuki, Tōru (2013). Low Fertility and Population Aging in Japan and Eastern Asia. Tokyo: Springer, https://doi.org/10.1007/978-4-431-54780-8.

Takahashi, Ryūsuke (2020). Fukushima Gov. Calls out Japan, Foreign Politicians for 'Chinese Virus' Comments, https://mainichi.jp/english/articles/20200324/ p2a/00m/0na/004000c (19 Jan. 2021).

The American Chamber of Commerce in Japan (2020). Statement on Re-entry Restrictions Placed on Permanent Residents and Visa Holders, https://static1. squarespace.com/static/5eb491d611335c743fef24ce/t/5ed8ad242aa608649c$0696 \mathrm{cb} / 1591258405032 / 200604+$ Statement+on+the+prohibition+on+the+entry+into+Japan+of+foreign+nationals+Clean.pdf (5 Jan. 2021).

The American Chamber of Commerce in Japan (2020). Second Statement on Re-entry Restrictions Placed on Permanent Resident and Visa Holders, https://static1.squarespace.com/static/5eb491d611335c743fef24ce/t/5f0433e6e9c21e3821625bca/15 94110951359/200707+Second+Statement+on+re-entry+travel+restrictions.pdf (5 Jan. 2021).

The American Chamber of Commerce in Japan (2020). Foreign Chambers Urge Prime Minister Suga to Engage with Foreign National Residents of Japan, https://static1. squarespace.com/static/5eb491d611335c743fef24ce/t/5fd1d084a9eaf43bd$8559 \mathrm{cfc} / 1607585924729 / 201208+F o r e i g n+C h a m b e r s+U r g e+P M+S u g a+t o+E n-$ gage+with+Foreign+Residents+2.pdf (5 Jan. 2021).

Tsuda, Takeyuki, Cornelius, Wayne A. (2004). Japan: Government Policy, Immigrant Reality. Controlling Migration: A Global Perspective (eds. Cornelius A. Wayne, Tsuda Takeyuki, Philip L. Martin, James F. Hollifield). Stanford, CA: Stanford University Press, 439-476.

Weber, Leanne, Bowling, Benjamin (2008). Valiant Beggars and Global Vagabonds: Select, Eject, Immobilize. Theoretical Criminology 12/3, 355-375, https://doi. org/10.1177/1362480608093311. 


\section{POVZETEK}

\section{VSTOP ZAVRNJEN: JAPONSKE MEJNE OMEJITVE V ČASU IZREDNIH RAZMER MED PANDEMIJO COVIDA-19 Nicola COSTALUNGA}

Globalna zdravstvena kriza, ki je izbruhnila leta 2020, je bila resen preizkus za številne nacionalne ekonomske, družbene in zdravstvene sisteme. Pandemija je pometla z gotovostjo človekovega vsakdanjega življenja in močno ogrozila splošni življenjski slog, tržno dinamiko in uveljavljene politike. Čeprav je bila sporna narava antivirusnih ukrepov enaka za vse, je novi koronavirus obstoječo družbeno neenakost še povečal in ustvaril pomembno vrzel med različnimi družbenimi neravnovesji, segmentacijo trga dela in drugimi vrstami neenakosti. Poleg že obstoječih so se pojavile še nove prepreke.

Vse te spremembe so prizadele tudi Japonsko, ki je z uvedenimi ukrepi za zajezitev virusa zaprla državo in po politični presoji tujce obravnavala drugače kot domačine. Posebnost omenjenih političnih odločitev je bila, da so prizadele tudi ljudi z dovoljenjem za stalno (kot tudi za dolgoročno) bivanje, ki imajo zato že po definiciji pravico do stalnega bivanja na Japonskem. Ti politični ukrepi so med redkimi, ki vse tuje državljane obravnavajo enako, ne glede na njihovo strokovno usposobljenost.

Članek osvetljuje ukrepe Japonske v zvezi s tujimi državljani in odziv na varnostno in zdravstveno situacijo, ki je že obstoječe probleme in rasna vprašanja še zaostril. Prvi del članka povzema splošno teorijo dinamike migracijskih in nadzornih politik, nato pa se podrobneje ukvarja z diferenciranimi ukrepi, vprašanji mejnega nadzora in s kulturnimi posebnostmi dežele. $V$ drugem delu opisuje dogodke, povezane s prepovedjo ponovnega vstopa tujih državljanov na Japonsko leta 2020, hkrati pa analizira trende diferenciacije v sodobni japonski družbi. Avtor članek konča z razmišljanji o družbeni diferenciaciji na Japonskem danes in z napovedmi za prihodnost. 